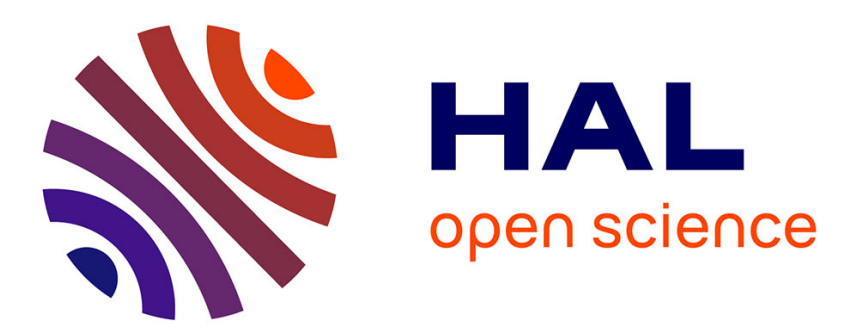

\title{
Lactosylceramide induced by elastin-derived peptides decreases adipocyte differentiation
}

Thinhinane Hocine, Sebastien Blaise, Cathy Hachet, Alexandre Guillot, Herve Sartelet, Pascal Maurice, Amar Bennasroune, Laurent Martiny, Laurent Duca, Beatrice Romier-Crouzet, et al.

\section{To cite this version:}

Thinhinane Hocine, Sebastien Blaise, Cathy Hachet, Alexandre Guillot, Herve Sartelet, et al.. Lactosylceramide induced by elastin-derived peptides decreases adipocyte differentiation. Journal of Physiology and Biochemistry, 2020, 76 (3), pp.457-467. 10.1007/s13105-020-00755-z . hal-02991996

\section{HAL Id: hal-02991996 https://hal.science/hal-02991996}

Submitted on 16 Nov 2020

HAL is a multi-disciplinary open access archive for the deposit and dissemination of scientific research documents, whether they are published or not. The documents may come from teaching and research institutions in France or abroad, or from public or private research centers.
L'archive ouverte pluridisciplinaire HAL, est destinée au dépôt et à la diffusion de documents scientifiques de niveau recherche, publiés ou non, émanant des établissements d'enseignement et de recherche français ou étrangers, des laboratoires publics ou privés. 


\section{cosyl-Ceramide induced by Elastin Derived Peptides, decrease adipocyte differentiati}

inane Hocine*, Sebastien Blaise*, Cathy Hachet, Alexandre Guillot, Herve Sartelet, Pascal Maurice,

Bennasroune, Laurent Martiny, Laurent Duca , Beatrice Romier-Crouzet*, and Hassan El Btaouri*\$

UMR CNRS 7369 MEDyC, SFR CAP-Sante, Université de Reims Champagne-Ardenne, France

* These authors contributed equally to this work.

\section{CORRESPONDING AUTHOR}

\$: Hassan EL BTAOURI UMR-CNRS 7369 Matrice Extracellulaire et Dynamique Cellulaire (MEDyC), UFR Sciences Exactes et Naturelles, Université de Reims Champagne Ardenne, Moulin de la Housse, BP 1039, 51687 Reims cedex, FRANCE.

E-mail : hassan.elbtaouri@univ-reims.fr

\section{ABSTRACT}

Elastin, major protein of extracellular matrix, is specially found in cardiovascular tissues and contributing to $30-50 \%$ of the dry weight of blood vessels. Elastin regulates cell signalling pathways involved in morphogenesis, injury response, and inflammation. The function of elastin is frequently compromised in damaged or aged elastic tissues. Indeed, elastin degradation, observed during ageing, and the resulting production of elastin derived peptides (EDP), have crucial impacts on cardiovascular disease (atherosclerosis, thrombosis) or on metabolism disease progressions (type 2 diabetes or non-alcoholic steatohepatitis).

In the present study, we analysed the EDP effects on 3 T3 pre-adipocyte cell differentiation. In a first part, we treated 3T3-L1 cells with EDP and visualized the lipid droplet accumulation by the oil red-O staining and measured the expression of various transcription factors and adipocyte-specific mRNAs by real-time RT-PCR. We demonstrated that elastin receptor complex, ERC, is activated by EDPs and decreased adipocyte differentiation by a modulation of crucial adipogenesis transcriptional factor particularly PPARy. In a second part, we identified the signalling pathway implicated in EDP-reduced cell differentiation. The flow cytometry and immunocytochemistry approaches showed that ERC activated by EDP, produced a second messenger, lactosylceramide (Lac-Cer). Moreover, this Lac-Cer production favoured the phosphorylation of ERK1-2 ( $p$ ERK1-2), to decrease adipocyte differentiation by a modulation of adipogenesis transcriptional factor PPAR To conclude, the EDP/Lac-Cer/p-ERK1-2 signalling pathway may be studied further as a critical target for treating complications associated with adipocyte dedifferentiation such as obesity and diabetes insulin resistance.

\section{KEY POINTS}

Elastin Derived Peptides (EDP) decreased PPARy expression.

EDP reduced adipocytes differentiation.

Adipocytes differentiation is reduced by Lac-cer production and ERK1/2 activation.

\section{KEYWORDS}

Elastin derived peptides, PPAR $\gamma$, adipocyte, Lactosyl-ceramide, Differentiation, ERK. 
ugh obesity is a huge challenge to global health, clinicians have had little success in fighting this dis

Over the past decade, several defective genes have been associated with obesity in humans such as genes involved in appetite control [10]. However, such genetic mutations do not always explain the high rate of obese people. Indeed, age, environment and eating habits are the main factor leading to obesity. Research on this disease has focused on strategies for treating complications associated with obesity instead of focusing on the major risk factors that affect this pathology. In the progression of this disease, the extracellular matrix (EMC) play a key role in adipose tissue remodeling. Thus the several studies demonstrated that proteases released by adipocytes, macrophages such as Cathepsin S, MMP-11, MMP-2, MMP-12,... or the cleavage, folding alteration of collagen $\mathrm{VI}$ and the production of endotrophin, might influence adipogenesis [20; 28]. Among the proteases mentioned, Cathepsin S, MMP12 or MMP2 belong to the family of elastases, and involved to elastin degradation. Elastin is crucial for normal development and is a major protein in adult cardiovascular tissues, contributing $30-50 \%$ of the dry weight of blood vessels [2]. Elastin endow tissues with elastic recoil and resilience [21], acting as an important adhesion template for cells, and regulating cell signaling pathways involved in morphogenesis, injury response, and inflammation Kielty [15]. Mutations in major structural components of elastic fibers, especially elastin, fibrillins and fibulin5, cause severe, often life-threatening diseases such as Marfan syndrome, supravalvular aortic stenosis and cutis laxa [15]. The function of elastic fibers is also frequently compromised in damaged or aged elastic tissues [19]. Indeed, fragmentation of elastin into elastin derived peptides, (EDP) during ageing has crucial impacts on cardiovascular diseases such atherosclerosis, thrombosis and metabolism diseases [5; 11; 14; 24]. Recently, our team and others have shown that elastases (i.e. neutrophil elastase) are involved on elastin fragmentation and EDP induced by elastases increased obesity, insulin resistance and type 2 diabetes [17; 24; 29; 32]. During the last decade, our team has deciphered the signaling pathways triggered by the elastin receptor complex (ERC) upon its binding to the canonical human sequence VGVAPG. This receptor has a very singular composition that comprises three subunits: a peripheral $67 \mathrm{kDa}$ subunit named Elastin Binding Protein (EBP) or S-Gal (spliced-galactosidase) and two membrane associated proteins, a $55 \mathrm{kDa}$ protective protein/cathepsin A (PPCA) and a $61 \mathrm{kDa}$ neuraminidase (Neuraminidase-1, Neu1). Although the role is still unknown, the PPCA subunit may contribute to the structural integrity of the ERC. The precise role of Neu1, the only receptor subunit with a cytosolic C-terminal tail, is still under investigation [31]. So far, the role of Neu1 within the receptor complex was unknown and results from our group showed that, the catalytic activity of Neu-1 is essential for signal transduction by the ERC [8]. Neu-1 could directly cleave sialic acids either of $\mathrm{N}$-glycosylation chain of receptor such as insulin receptor (IR) [5] or of the ceramide such as GM3 ganglioside to product lactosylceramide (Lac-Cer), which is now regarded as the second messenger of the ERC [25]. Binding of EDP to the ERC results in a host of signaling events that depend on cell types and therefore on the triggering of specific signaling cascades such as MEK1/2 activation, PI3K $\gamma$ pathway [9; 11]. 
Becas e ceramides are described as a major markers of obesity, we suspected that Lac-Cer producea

iver-sofwated might an important role in obesity and adipose homeostasis. Therefore, in this study, we analy

the bioactive elastin-derived peptides (EDP) effect on 3T3-L1 fibroblast cell differentiation. We showed that EDP/ERC interaction converted the GM3 ganglioside to Lac-Cer. Lac-Cer acted such as second messenger to activate ERK1-2 pathway, to inhibit the expression of PPAR $\gamma$ and adipogenesis-specific factors and to decrease 3T3-L1 cell differentiation. The EDP/Lac-Cer/ERK1-2 signaling pathway may be studied further as a critical target for treating complications associated with adipocyte dedifferentiation such as obesity and diabetes insulin resistance. 
1 fibroblast cells were purchased from ATCC (Manassa, USA). EDPs was obtained by KOH hydrolys described previously [24]. The synthetic elastin (VGVAPG) and scramble (VVGPGA) peptides were purchased from GeneCust (Dudelange, Luxembourg).

\section{Cell line and culture conditions}

3T3-L1 fibroblast cells were cultured and growing to confluence in Dulbecco's modified eagle medium (DMEM) supplemented with $10 \%(\mathrm{v} / \mathrm{v})$ fetal bovine serum (FBS), $100 \mathrm{U} / \mathrm{mL}$ penicillin and $100 \mu \mathrm{g} / \mathrm{mL}$ streptomycin (Invitrogen). Two days postconfluence, the cells were cultured for $48 \mathrm{~h}$ in adipogenesisinducing medium (DMI) containing $0.25 \mu \mathrm{M}$ dexamethasone, $0.5 \mathrm{mM}$ 3-isobutyl-1-methylxanthine, and 1.5 $\mu \mathrm{M}$ insulin, supplemented with $10 \% \mathrm{FBS}$ and $100 \mathrm{U} / \mathrm{mL}$ penicillin and $100 \mu \mathrm{g} / \mathrm{mL}$ streptomycin in presence or absence of different agonists. This point was considered as zero of differentiation day $\left(D_{0}\right)$. Then, 3T3-L1 cells were incubated at different times in DMEM medium supplemented with $10 \% \mathrm{FBS}, 100 \mathrm{U} / \mathrm{mL}$ penicillin and $100 \mu \mathrm{g} / \mathrm{mL}$ streptomycin and $1.5 \mu \mathrm{M}$ insulin in presence or absence of different agonists.

\section{Cell viability assay}

Cells were plated in microwell plates at $10^{4}$ cells $/ \mathrm{mL}$ and incubated for $D_{0}$ to $D_{9}$ with or without EDP (50 $\mu \mathrm{g} / \mathrm{ml}$ ) UptiBlue $10 \%(\mathrm{v} / \mathrm{v})$ was added in cultured medium. Plates were incubated for an additional $3 \mathrm{~h}$ and

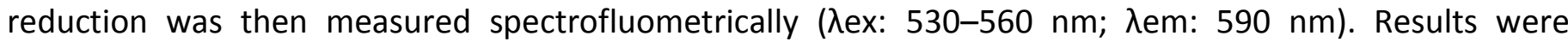
calculated as percent of controls as follows: (Experimental absorbance / untreated control absorbance) $\times 100$.

\section{Oil Red O Staining}

Accumulation of triglycerides was visualized by staining with Oil red O (Sigma-Aldrich), essentially as described previously [33]. Briefly, we prepared a stock solution of $0.5 \%(w / v)$ Oil red 0 in isopropanol. To achieve a working concentration, $6 \mathrm{~mL}$ of stock solution was mixed with $4 \mathrm{~mL}$ of water. The cells were directly fixed in situ with $10 \%$ buffered formaldehyde at $40^{\circ} \mathrm{C}$ for 1 hour, washed with phosphate-buffered saline (PBS), stained with Oil red O working solution for 15 minutes, and finally washed with water. The triglyceride accumulation was assessed microscopically with inverted microscope

\section{RNA preparation and quantitative RT-PCR.}

RNA were isolated as described previously [4] and converted to cDNA using SuperScript II RT (Invitrogen Life Technologies) and oligo dT24 primers. Quantitative RT-PCR was performed using the SYBR Green JumpStart PCR kit (Sigma-Aldrich, St. Louis, MO) according to the supplier's protocol. 36B4 and 18S RNAs were used as internal controls.

\section{Measurement of lactosyl-ceramide}

Flow cytometry: After stimulation, 3T3-L1 cells were washed with ice-cold PBS containing $50 \mathrm{mM} \mathrm{Na}_{3} \mathrm{VO}_{4}$ and harvested using PBS EDTA $10 \mathrm{mM}$ at $4^{\circ} \mathrm{C}$. Cells were centrifuged $\left(400 \mathrm{~g}, 10 \mathrm{~min}, 4^{\circ} \mathrm{C}\right)$, washed with PBS, 

$1 \%$ formaldehyde before being analysed with a FACS Calibur cytometer.

Immunofluorescence: Cells $\left(25 \times 10^{4}\right)$ were plated on glass-slides and incubated according to differentiation protocol with or without different agonists. The fixation of the samples was made using $4 \%(v / v)$ paraformaldehyde. The slides were washed with PBS, incubated with BSA 3\% (w/v) for 30 min and overnight with an anti-CD 17 antibody (anti-lactosylceramide). Then cells were washed with PBS and incubated for 45 min with an anti-rabbit Alexafluor-568 $\left({ }^{\mathrm{TM}}\right)$. Slides were incubated with mounting medium containing DAPI. Immunofluorescence-labelled cell preparations were analysed using a Zeiss LSM 710 confocal laser scanning microscope.

\section{Western blotting}

After stimulation, 3T3-L1 cells were washed with ice-cold PBS, lysed in ice cold buffer containing $10 \mathrm{mM}$ Tris $\mathrm{pH}$ 7.4, $150 \mathrm{mM} \mathrm{NaCl}, 5 \mathrm{mM}$ EDTA, $1 \mathrm{mM} \mathrm{Na} \mathrm{VO}_{4}, 1 \mathrm{mM}$ dithiothreitol, $10 \mu \mathrm{g} / \mathrm{mL}$ leupeptin, $10 \mu \mathrm{g} / \mathrm{mL}$ aprotinin, 10\% (vol/vol.) glycerol, 1\% Brij (vol./vol.), placed on ice for $20 \mathrm{~min}$ and then centrifuged (14000g, $15 \mathrm{~min}, 4^{\circ} \mathrm{C}$ to prepare whole cell extracts). The amount of proteins was determined using the BCA protein quantification kit (Interchim, Montluçon, France). Equal amounts of proteins (whole cell extracts) were resolved by $10 \%$ SDS-PAGE gels and transferred to nitrocellulose sheets and probed with the appropriate antibodies (polyclonal anti-Phospho ERK1-2, polyclonal anti-ERK1-2). Horseradish peroxidase-conjugated goat anti-rabbit was used as secondary antibodies and proteins were detected using an enhanced chemiluminescence (ECL) kit.

\section{Statistics}

Each experiment was performed at least in triplicate on three separate sets of culture. Data were expressed as mean $\pm S E M$. The statistical significance of differences was calculated using Student's test. $p$ values referring to corresponding control are $* *$ and ${ }^{\circledast \%} p<0.01, * * *$ and ${ }^{\cdots} p<0.001$. 
EDP were described to induce insulin resistance or Nonalcoholic steatohepatitis involved in metabolism syndrome. In this study, we wanted to know if EDP impact the adipocyte differentiation. Therefore, 3T3-L1 cells were treated with DMI (Dexamethasone, IBMX, Insulin) to induce adipocyte differentiation with or without Elastin-derived peptides (EDP) $(50 \mu \mathrm{g} / \mathrm{ml})$ according to Blaise et al.[5], and the lipid accumulation was visualized by the oil red-O staining on days $0,3,6$ and 9 (Fig. 1A). The lipid droplet accumulation in the cells appeared on day 3 and increased with the culture duration confirming the induction of differentiation. Whereas the stained area for Oil-red $O$ in the EDP-treated cells was significantly decreased by approximately $90 \%$ after 9 days of treatment. Under these same conditions, the cell viability was not affected by the different treatments as showed in Fig 1B.

Various transcription factors such as C/EBP- $\alpha, C / E B P-\beta$, PPAR- $\gamma$ and aP 2 and adipocyte-specific proteins (ACC, $A C D C, O b)$ are known to be expressed throughout the progression of adipogenesis [22]. So, we examined the influence of EDP on the expression of these adipogenesis-specific markers and factors by real-time RTPCR. As showed in Fig. $2 \mathrm{~A}$, from $6^{\text {th }}$ day of differentiation, we observed that expression of mature adipose markers such as $A C C, A C D C$ and $O b$ was significantly increased upon exposure to adipogenic stimuli according lipid droplet staining with Oil Red O. Treatment with EDP during differentiation significantly reduced the expression of these mature adipose markers. We also analyzed the expression of PPAR $\gamma, \mathrm{CEBP} \alpha$ and SREBP-1C, an adipogenesis-specific transcription factors. As showed in Fig 2B, the mature adipocytes expressed high levels of PPAR $\gamma, \mathrm{cEBP} \alpha$ and SREBP-1c. However, only PPAR $\gamma$ expression was abolished by EDP treatment cell. These results indicated that EDP significantly inhibited the differentiation of preadipocytes to mature adipocytes by down-regulating the expression of PPAR $\gamma$ transcription factors involved in lipid metabolism.

\section{ERC induced by EDP is associated to the decrease of adipocyte differentiation.}

The biological effects of EDP are mainly induced by Elastin receptor complex composed by 3 subunits,

"elastin binding protein", protective protein cathepsin A and neuraminidase 1. EBP and Neu-1 functions are inhibited by chondroitin sulfate (CS) and 2, 3-didehydro-2-deoxy-N-acetylneuraminic acid (DANA), respectively, according to Wahart et al. [31]. To confirm the involvement of ERC in EDP-inhibited 3T3-L1 differentiation, we treated at the same time 3T3-L1 cells by DMI with or without EDP $(50 \mu \mathrm{g} / \mathrm{ml})$ in presence or absence of DANA $(200 \mu \mathrm{M})$ or CS $(200 \mu \mathrm{g} / \mathrm{ml}) 6$ and 9 days. In the condition of DANA or CS, the oil red O staining increased as compared to EDP condition, suggesting that inhibitors of ERC favored lipid accumulation in 3T3-L1 during differentiation progression (Fig 3A). We demonstrated also that DANA and CS inhibited the effects of EDP on adiponectin and PPAR $\gamma$ expressions (Fig 3B). Those results suggested that ERC is involved in the EDP-reduced adipocyte differentiation and implicated neuraminidase 1. 
degradation by elastases generates elastin-derived peptides. Among them, peptides harbo

$\mathrm{G}$ consensus motif (where $\mathrm{x}$ represents any amino acid) are bioactive because this sequence mot

$5 ; 8 ; 11 ; 19 ; 25 ; 26]$. Here, we analyzed the VGVAPG peptide on 3T3-L1 differentiation (Fig 4). We showed that VGVAPG peptide reduced PPAR $\gamma$ and adiponectin expression and reduced 3T3-L1 cell differentiation compared to scramble peptide. Those results give a direct evidence for the involvement of ERC in the EDPreduced adipocyte differentiation.

\section{Lactosyl ceramide is involved to adipocyte differentiation.}

Previously, we demonstrated that ERC is responsive to the GM3 conversion into lactosyl ceramide (Lac-Cer) [25]. Therefore, we measured by Flow cytometry and immunocytochemistry the Lac-Cer accumulation after 6, 12 and 24h of EDP adipocyte treatment with or without DANA $(200 \mu \mathrm{M})$ or CS $(200 \mu \mathrm{g} / \mathrm{ml})$. Fig. 5 and 6 showed that EDP induced an increase of Lac-Cer level. This effect was amplified up to $12 \mathrm{~h}$. However, Lac-Cer level was slightly affected in presence of DANA or CS. These results suggested the implication of ERC in EDPinduced Lac-Cer production. To confirm that Lac-Cer was responsible for EDP-inhibited 3T3-L1 differentiation, we treated 3T3-L1 cells by DMI with or without exogenous Lac-Cer (2 and $10 \mu \mathrm{M})$ for 6 and 9 days. The lipid accumulation analyzed by the oil red-O staining is reduced and is dependent to the Lac-Cer concentrations (Fig 7). As expected, Lac-Cer mimicked the EDP effect such as reduction of adiponectin and PPAR $\gamma$ expression confirming the decrease of 3T3-L1 cell differentiation (Fig 7).

\section{ERK1-2 pathway and adipocyte differentiation}

In our previous studies [25], we characterized Lac-Cer as a second messenger able to activate intracellular signals, in particularly ERK1-2 pathway. So, we analyzed the phosphorylation of ERK1-2 following EDP treatment cells. We treated 3T3-L1 cells by DMI with or without EDP $(50 \mu \mathrm{g} / \mathrm{ml})$ or Lac-Cer $(2 \mu \mathrm{M})$ in presence or absence of DANA $(200 \mu \mathrm{M})$ for $0.5,1$ and $2 \mathrm{~h}$. We analyzed the ERK1-2 phosphorylation by western blot. As shown in Fig. 8, EDP treatment cells induced ERK1-2 phosphorylation. This effect was significant up to 60 min and implicated ERC signaling pathway. DANA treatment cells inhibited EDP-induced ERK1-2 activation. Similarly, addition of exogenous Lac-Cer in cell medium reproduced the same EDP effects such as the ERK12 phosphorylation in same time. In order to determine the role of ERK1-2 phosphorylation in EDP-inhibited 3T3-L1 cell differentiation, we treated 3T3-L1 cells by DMI with or without EDP $(50 \mu \mathrm{g} / \mathrm{ml})$ or exogenous LacCer $(2 \mu \mathrm{M})$ in presence or absence of MEK-1,2 Inhibitor (U0126) at $10 \mu \mathrm{M}$ for 6 and 9 days and analyzed the degree of differentiation by the oil red-O staining and adiponectin and PPAR $\gamma$ expression by qPCR. As expected, EDP and Lac-Cer inhibited adiponectin and PPAR $\gamma$ expression and reduced the 3T3-L1 cell differentiation (Fig 9). Moreover, the presence of U0126 abolished the EDP and Lac-Cer effects and restored the 3T3-L1 cell differentiation. This result confirmed the implication of ERK1-2 pathway in EDP-reduced 3T3L1 cell differentiation and implicated Lac-Cer such as second messenger. 
ata provide important point regarding the relative contribution of ceramides, in particularly Lac the obesity. In our study, we demonstrated for the first time that Lac-Cer reduced the adipocyte differentiation. Circulating ceramides were described to be a strong markers of metabolic dysfunction, such as type 2 diabetes, lipid accumulation in liver or in adipose tissue. Thus, GM3 is particularly abundant in those organs, wherein it comprises between $80 \%$ and $90 \%$ of total ganglioside content, respectively. It plays a major role in modulating insulin sensitivity and energy homeostasis [23]. In accord with this, 3T3-L1 adipocytes incubated with exogenous GM3, presented a decrease of phosphorylation of insulin receptor phosphorylation and that of IRS-1, concomitant with impaired insulin-stimulated glucose uptake [7]. In parallel GM3 is involved in lipid accumulation, inducing then an hypertrophy of adipocytes. GM3 acts as a metabolic precursor for the formation of more complex gangliosides. Indeed, gangliosides can be degraded through hydrolytic cleavage of sialic acid chains by the action of sialidase enzymes (such as Neuraminidase1 ou -3) localized in lysosome or in cell membranes. Neu-1 can be found at the plasma membrane coupled to either PPCA (protective protein cathesine A) or PPCA and EBP (elastin binding protein), thus called ERC, elastin receptor complex [3]. ERC is activated by elastin-derived peptides (EDP) and induce several signaling events beginning by sialic acid cleavage of GM3 into Lactosyl-Ceramide (Lac-Cer). Lac-Cer as an intermediate in the synthesis of complex sphingolipids. Nevertheless, recent works demonstrated this Lac-Cer is also a bioactive sphingolipid which regulates various cell signaling pathways and can be considered as a second messenger. Thus the conversion of ganglioside GM3 into Lac-Cer by the Neuraminidase-1 activated by EDP favored the MAPK pathway in cells, the proliferation or the migration of cells. In pre-adipocyte, we demonstrated that Lac-Cer could be produced by the elastin receptor complex activation on the one hand and on the other hand, induced the phosphorylation of ERK $1 / 2$. Additionally, we showed here that 3T3-L1 cells incubated with Lac-Cer or produced by EDP stimulations cause reduction in the protein levels of the crucial adipogenesis marker PPARy, which is both necessary and sufficient for adipocyte differentiation[16]. Thereby suggesting that the Lac-Cer production might be detrimental for optimal adipogenic differentiation. Using a specific ERK inhibitor which reversed the reduction in PPARY [30], suggested that EDP - Lac-Cer ERK1-2 pathway was involved in PPARY activity or transcription. Indeed, PPAR p presents an activation function called (AF)-1 domain corresponding a consensus mitogen-activated protein kinase (MAPK) site. The phosphorylation by extracellular signal-regulated kinase (ERK)-1/2) leads to inhibition of PPAR transactivation $[1 ; 6]$ and to degradation of PPARY by the ubiquitin-proteasome system [12]. Adipocyte differentiation needs the activation of two cascades of transcription factors. The first is transiently induced by adipogenic stimuli and involves CCAAT/enhancer-binding protein- $\beta$ and $-\delta$ (C/EBP- $\beta$ and C/EBP- $\delta$, respectively). In turn, those factors directly induce expression of the second wave, consisting of PPARY and C/EBP $\alpha$. Transactivation domain (RD2) of C/EBP- $\beta$ contains a threonine (T235), essential for gene expression. The phosphorylation by ERK1-2 of this threonine regulate C/EBP- $\beta$-dependent gene stimulatory 
Interestingly, in previous studies, we showed, that exogenous EDP injections increase the fat pad of young adult mice, fed with non-energetic diet. The size of perigonadal adipocytes presented a large lipid droplet suggesting that EDP and ERC activation are responsive to adipocyte hypertrophy and to overweight of mice. From 3T3-L1 mature adipocytes EDP induced an oil-Red-O accumulation and an increase of mRNA levels of PPAR $\gamma$ and $C / E B P \alpha$, confirming that EDP induces in vitro lipogenesis in mature adipocytes [5]. Here, our study showed that EDP inhibited the expression of transcription factors involved in differentiation of preadipocytes. With those two studies, we can suppose that EDP and ERC present a dual effect to exacerbate lipid storage in mature adipocyte but limit the formation of new adipocyte from preadipocytes. This point is crucial in the obesity development. Indeed, recent studies showed in obese animal models or patients, that matrix remodeling is major: Large areas of fibrosis, a high expression of proteases and curiously an elastin expression [18; 27]. In physiological condition, elastin biosynthesis starts during the fetal stage and reaches a peak just before birth, in 3 main tissues (skin, lungs, and large arteries). The process of elastogenesis, which consists in formation of elastic fibers, decreases during early life to disappear at puberty. Finally, elastin production is low or inexistent during adulthood. During obesity, the expression of elastases such as cathepsin S or MMP2, MMP9 or MMP12, in adipose tissue, can degrade newly synthesized elastin to form EDP. Thus those EDP might be considered as a protective factor to limiting the adipocyte differentiation. In conclusion, we demonstrated in this studies that EDP produced by elastin degradation during ageing or obesity, is responsible to a decrease of adipocyte differentiation. Molecular mechanism involved the formation of Lac-Cer and ERK $1 / 2$ pathway activation which might explain a PPAR $\gamma$ decrease.

\section{ACKNOWLEDGMENTS}

We thank Stephane Betoulle for her technical support with Flow cytometry. This work was supported by the University of Reims Champagne Ardennes and the Centre National de la Recherche Scientifique (CNRS). 
no significant financial support for this work that could have influenced its outcome.

This work does not involve humans or animals. 
ADAMS, M., REGINATO, M.J., SHAO, D., LAZAR, M.A., and CHATTERJEE, V.K., 1997. Transcriptional act by peroxisome proliferator-activated receptor gamma is inhibited by phosphorylation at a consensus mitoget:activated protein kinase site. J Biol Chem 272, 8 (Feb 21), 5128-5132. DOI= http://dx.doi.org/10.1074/jbc.272.8.5128.

[2] BASHUR, C.A., VENKATARAMAN, L., and RAMAMURTHI, A., 2012. Tissue engineering and regenerative strategies to replicate biocomplexity of vascular elastic matrix assembly. Tissue Eng Part B Rev 18, 3 (Jun), 203217. DOI= http://dx.doi.org/10.1089/ten.TEB.2011.0521.

[3] BENNASROUNE, A., ROMIER-CROUZET, B., BLAISE, S., LAFFARGUE, M., EFREMOV, R.G., MARTINY, L., MAURICE, P., and DUCA, L., 2019. Elastic fibers and elastin receptor complex: Neuraminidase-1 takes the center stage. Matrix Bio/(Jun 18). DOI= http://dx.doi.org/10.1016/i.matbio.2019.06.007.

[4] BLAISE, S., KNEIB, M., ROUSSEAU, A., GAMBINO, F., CHENARD, M.P., MESSADEQ, N., MUCKENSTRUM, M., ALPY, F., TOMASETTO, C., HUMEAU, Y., and RIO, M.C., 2012. In vivo evidence that TRAF4 is required for central nervous system myelin homeostasis. PLoS One 7, 2, e30917. DOI= http://dx.doi.org/10.1371/journal.pone.0030917.

[5] BLAISE, S., ROMIER, B., KAWECKI, C., GHIRARDI, M., RABENOELINA, F., BAUD, S., DUCA, L., MAURICE, P., HEINZ, A., SCHMELZER, C.E., TARPIN, M., MARTINY, L., GARBAR, C., DAUCHEZ, M., DEBELLE, L., and DURLACH, V., 2013. Elastin-derived peptides are new regulators of insulin resistance development in mice. Diabetes 62, 11 (Nov), 3807-3816. DOI= http://dx.doi.org/10.2337/db13-0508.

[6] CAMP, H.S. and TAFURI, S.R., 1997. Regulation of peroxisome proliferator-activated receptor gamma activity by mitogen-activated protein kinase. J Biol Chem 272, 16 (Apr 18), 10811-10816. DOI= http://dx.doi.org/10.1074/jbc.272.16.10811.

[7] CHAVEZ, J.A., SIDDIQUE, M.M., WANG, S.T., CHING, J., SHAYMAN, J.A., and SUMMERS, S.A., 2014. Ceramides and glucosylceramides are independent antagonists of insulin signaling. J Biol Chem 289, 2 (Jan 10), 723-734. DOI= http://dx.doi.org/10.1074/jbc.M113.522847.

[8] DUCA, L., BLANCHEVOYE, C., CANTARELLI, B., GHONEIM, C., DEDIEU, S., DELACOUX, F., HORNEBECK, W., HINEK, A., MARTINY, L., and DEBELLE, L., 2007. The elastin receptor complex transduces signals through the catalytic activity of its Neu-1 subunit. J Biol Chem 282, 17 (Apr 27), 12484-12491. DOI= http://dx.doi.org/10.1074/ibc.M609505200.

[9] DUCA, L., LAMBERT, E., DEBRET, R., ROTHHUT, B., BLANCHEVOYE, C., DELACOUX, F., HORNEBECK, W., MARTINY, L., and DEBELLE, L., 2005. Elastin peptides activate extracellular signal-regulated kinase $1 / 2$ via a Ras-independent mechanism requiring both p110gamma/Raf-1 and protein kinase A/B-Raf signaling in human skin fibroblasts. Mol Pharmacol 67, 4 (Apr), 1315-1324. DOI= http://dx.doi.org/10.1124/mol.104.002725.

[10] FAROOQI, I.S. and O'RAHILLY, S., 2004. Monogenic human obesity syndromes. Recent Prog Horm Res 59, 409424.

[11] GAYRAL, S., GARNOTEL, R., CASTAING-BERTHOU, A., BLAISE, S., FOUGERAT, A., BERGE, E., MONTHEIL, A., MALET, N., WYMANN, M.P., MAURICE, P., DEBELLE, L., MARTINY, L., MARTINEZ, L.O., PSHEZHETSKY, A.V., DUCA, L., and LAFFARGUE, M., 2014. Elastin-derived peptides potentiate atherosclerosis through the immune Neu1-PI3Kgamma pathway. Cardiovasc Res 102, 1 (Apr 1), 118-127. DOI= http://dx.doi.org/10.1093/cvr/cvt336.

[12] HAUSER, S., ADELMANT, G., SARRAF, P., WRIGHT, H.M., MUELLER, E., and SPIEGELMAN, B.M., 2000. Degradation of the peroxisome proliferator-activated receptor gamma is linked to ligand-dependent activation. J Biol Chem 275, 24 (Jun 16), 18527-18533. DOI= http://dx.doi.org/10.1074/jbc.M001297200.

[13] HU, J., ROY, S.K., SHAPIRO, P.S., RODIG, S.R., REDDY, S.P., PLATANIAS, L.C., SCHREIBER, R.D., and KALVAKOLANU, D.V., 2001. ERK1 and ERK2 activate CCAAAT/enhancer-binding protein-beta-dependent gene transcription in response to interferon-gamma. J Biol Chem 276, 1 (Jan 5), 287-297. DOI= http://dx.doi.org/10.1074/jbc.M004885200.

[14] KAWECKI, C., HEZARD, N., BOCQUET, O., POITEVIN, G., RABENOELINA, F., KAUSKOT, A., DUCA, L., BLAISE, S., ROMIER, B., MARTINY, L., NGUYEN, P., DEBELLE, L., and MAURICE, P., 2014. Elastin-derived peptides are new regulators of thrombosis. Arterioscler Thromb Vasc Biol 34, 12 (Dec), 2570-2578. DOI= http://dx.doi.org/10.1161/ATVBAHA.114.304432.

[15] KIELTY, C.M., 2006. Elastic fibres in health and disease. Expert Rev Mol Med 8, 19, 1-23. DOI= http://dx.doi.org/10.1017/s146239940600007x.

[16] LODHI, I.J. and SEMENKOVICH, C.F., 2014. Peroxisomes: a nexus for lipid metabolism and cellular signaling. Cell Metab 19, 3 (Mar 4), 380-392. DOI= http://dx.doi.org/10.1016/i.cmet.2014.01.002.

[17] MANSUY-AUBERT, V., ZHOU, Q.L., XIE, X., GONG, Z., HUANG, J.Y., KHAN, A.R., AUBERT, G., CANDELARIA, K., THOMAS, S., SHIN, D.J., BOOTH, S., BAIG, S.M., BILAL, A., HWANG, D., ZHANG, H., LOVELL-BADGE, R., SMITH, 
S.R., AWAN, F.R., and JIANG, Z.Y., 2013. Imbalance between neutrophil elastase and its inhibitor antitrypsin in obesity alters insulin sensitivity, inflammation, and energy expenditure. Cell Metab 17, 4 534-548. DOI= http://dx.doi.org/10.1016/i.cmet.2013.03.005.

[18] MARTINEZ-SANTIBANEZ, G., SINGER, K., CHO, K.W., DELPROPOSTO, J.L., MERGIAN, T., and LUMENG, C.N., 2015. Obesity-induced remodeling of the adipose tissue elastin network is independent of the metalloelastase MMP-12. Adipocyte 4, 4 (Oct-Dec), 264-272. DOI= http://dx.doi.org/10.1080/21623945.2015.1027848.

[19] MAURICE, P., BLAISE, S., GAYRAL, S., DEBELLE, L., LAFFARGUE, M., HORNEBECK, W., and DUCA, L., 2013. Elastin fragmentation and atherosclerosis progression: the elastokine concept. Trends Cardiovasc Med 23, 6 (Aug), 211-221. DOI= http://dx.doi.org/10.1016/j.tcm.2012.12.004.

[20] MOTRESCU, E.R., BLAISE, S., ETIQUE, N., MESSADDEQ, N., CHENARD, M.P., STOLL, I., TOMASETTO, C., and RIO, M.C., 2008. Matrix metalloproteinase-11/stromelysin-3 exhibits collagenolytic function against collagen $\mathrm{VI}$ under normal and malignant conditions. Oncogene 27, 49 (Oct 23), 6347-6355. DOI= http://dx.doi.org/10.1038/onc.2008.218.

[21] NAKAMURA, T., LOZANO, P.R., IKEDA, Y., IWANAGA, Y., HINEK, A., MINAMISAWA, S., CHENG, C.-F., KOBUKE, K., DALTON, N., TAKADA, Y., TASHIRO, K., ROSS JR, J., HONJO, T., and CHIEN, K.R., 2002. Fibulin-5/DANCE is essential for elastogenesis in vivo. Nature 415, 6868 (01/10/print), 171-175. DOI= http://dx.doi.org/http://www.nature.com/nature/journal/v415/n6868/suppinfo/415171a S1.html.

[22] NTAMBI, J.M. and YOUNG-CHEUL, K., 2000. Adipocyte differentiation and gene expression. J Nutr 130, 12 (Dec), 3122S-3126S. DOI= http://dx.doi.org/10.1093/in/130.12.3122S.

[23] PROKAZOVA, N.V., SAMOVILOVA, N.N., GRACHEVA, E.V., and GOLOVANOVA, N.K., 2009. Ganglioside GM3 and its biological functions. Biochemistry (Mosc) 74, 3 (Mar), 235-249.

[24] ROMIER, B., IVALDI, C., SARTELET, H., HEINZ, A., SCHMELZER, C.E.H., GARNOTEL, R., GUILLOT, A., JONQUET, J., BERTIN, E., GUEANT, J.L., ALBERTO, J.M., BRONOWICKI, J.P., AMOYEL, J., HOCINE, T., DUCA, L., MAURICE, P., BENNASROUNE, A., MARTINY, L., DEBELLE, L., DURLACH, V., and BLAISE, S., 2018. Production of Elastin-Derived Peptides Contributes to the Development of Nonalcoholic Steatohepatitis. Diabetes 67, 8 (Aug), 1604-1615. DOI= http://dx.doi.org/10.2337/db17-0490.

[25] RUSCiANI, A., DUCA, L., SARTElet, H., CHATRON-COlliet, A., BOBICHON, H., PLOTON, D., LE NAOUR, R., BLAISE, S., MARTINY, L., and DEBELLE, L., 2010. Elastin peptides signaling relies on neuraminidase-1-dependent lactosylceramide generation. PLoS One 5, 11 (Nov 16), e14010. DOI= http://dx.doi.org/10.1371/journal.pone.0014010.

[26] SCANDOlera, A., RABEnoelinA, F., CHAintreUIL, C., RUSCIANI, A., MAURICE, P., BLAISE, S., ROMIERCROUZET, B., EL BTAOURI, H., MARTINY, L., DEBELLE, L., and DUCA, L., 2015. Uncoupling of Elastin Complex Receptor during In Vitro Aging Is Related to Modifications in Its Intrinsic Sialidase Activity and the Subsequent Lactosylceramide Production. PLoS One 10, 6, e0129994. DOI= http://dx.doi.org/10.1371/journal.pone.0129994.

[27] SPENCER, M., UNAL, R., ZHU, B., RASOULI, N., MCGEHEE, R.E., JR., PETERSON, C.A., and KERN, P.A., 2011. Adipose tissue extracellular matrix and vascular abnormalities in obesity and insulin resistance. $J$ Clin Endocrinol Metab 96, 12 (Dec), E1990-1998. DOI= http://dx.doi.org/10.1210/ic.2011-1567.

[28] TALEB, S. and CLEMENT, K., 2007. Emerging role of cathepsin S in obesity and its associated diseases. Clin Chem Lab Med 45, 3, 328-332. DOI= http://dx.doi.org/10.1515/CCLM.2007.083.

[29] TALUKDAR, S., OH, D.Y., BANDYOPADHYAY, G., LI, D., XU, J., MCNELIS, J., LU, M., LI, P., YAN, Q., ZHU, Y., OFRECIO, J., LIN, M., BRENNER, M.B., and OLEFSKY, J.M., 2012. Neutrophils mediate insulin resistance in mice fed a high-fat diet through secreted elastase. Nat Med 18, 9 (Sep), 1407-1412. DOI= http://dx.doi.org/10.1038/nm.2885.

[30] TANABE, Y., KOGA, M., SAITO, M., MATSUNAGA, Y., and NAKAYAMA, K., 2004. Inhibition of adipocyte differentiation by mechanical stretching through ERK-mediated downregulation of PPARgamma2. J Cell Sci 117, Pt 16 (Jul 15), 3605-3614. DOI= http://dx.doi.org/10.1242/jcs.01207.

[31] WAHART, A., HOCINE, T., ALBRECHT, C., HENRY, A., SARAZIN, T., MARTINY, L., EL BTAOURI, H., MAURICE, P., BENNASROUNE, A., ROMIER-CROUZET, B., BLAISE, S., and DUCA, L., 2019. Role of elastin peptides and elastin receptor complex in metabolic and cardiovascular diseases. FEBS J(Apr 4). DOI= http://dx.doi.org/10.1111/febs.14836.

[32] WONG, H., PRÉVOTEAU-JONQUET, J., BAUD, B., DAUCHEZ, M., and BELLOY, N., 2018. Mesoscopic Rigid Body Modelling of the Extracellular Matrix Self-Assembly. Journal of Integrative Bioinformatics, 6-11.

[33] YUN, Z., MAECKER, H.L., JOHNSON, R.S., and GIACCIA, A.J., 2002. Inhibition of PPAR gamma 2 gene expression by the HIF-1-regulated gene DEC1/Stra13: a mechanism for regulation of adipogenesis by hypoxia. Dev Cell 2, 3 (Mar), 331-341. 
0 
figu 1 1: 3T3-L1 fibroblast cells were incubated at zero of differentiation day (D0) with or without

$\left.\mathrm{L}^{-1}\right)$ for 3, 6 and 9 days. Lipid droplet accumulation was visualized the by the oil red-O staini

assessed microscopically with inverted microscope (A). Cell viability was measured using UptiBlue assay. Results were calculated as percent of control and represent mean \pm standard deviation (S.D.) of at least three independent experiments (B).

Figure 2: 3T3-L1 fibroblast cells were incubated at zero of differentiation day (D0) with or without EDP (50 $\mu \mathrm{g} . \mathrm{mL}^{-1}$ ) for 3, 6 and 9 days. The expression of adipogenesis-specific markers (A) and adipogenesis-specific transcription factors (B) was analysed by Quantitative RT-PCR using the SYBR Green JumpStart PCR kit. Results were calculated as percent of control and represent mean \pm standard deviation (S.D.) of at least three independent experiments.

Figure 3: 3T3-L1 fibroblast cells were incubated at zero of differentiation day (D0) with or without EDP (50 $\left.\mu \mathrm{g} . \mathrm{mL}^{-1}\right)$, DANA $(400 \mu \mathrm{M})$ and CS $\left(200 \mu \mathrm{g} \cdot \mathrm{mL}^{-1}\right)$ for 6 and 9 days. Lipid droplet accumulation was visualized the by the oil red-O staining and assessed microscopically with inverted microscope (A). The expression of ACDC and PPAR $\gamma$ was analysed by Quantitative RT-PCR. Results were calculated as percent of control and represent mean \pm standard deviation (S.D.) of at least three independent experiments (B).

Figure 4: 3T3-L1 fibroblast cells were incubated at zero of differentiation day (D0) with VGVAPG peptide or scramble peptide $\left(50 \mu \mathrm{g} \cdot \mathrm{mL}^{-1}\right)$ for 9 days. Lipid droplet accumulation was visualized the by the oil red-O staining and assessed microscopically with inverted microscope. The expression of ACDC and PPAR $\gamma$ was analysed by Quantitative RT-PCR. Results were calculated as percent of control and represent mean \pm standard deviation (S.D.) of at least three independent experiments.

Figure 5: 3T3-L1 fibroblast cells were incubated on glass-slides at zero of differentiation day (D0) with or without EDP $\left(50 \mu \mathrm{g} . \mathrm{mL}^{-1}\right)$, DANA $(400 \mu \mathrm{M})$ and $\mathrm{CS}\left(200 \mu \mathrm{g} \cdot \mathrm{mL}^{-1}\right)$ for 6,12 and 24 hours. Lactosyl-ceramide was visualised by immunofluorescence using an anti-CD 17 antibody (anti-lactosyl-ceramide) and an antirabbit Alexafluor-568 (TM). Immunofluorescence-labelled cell preparations were analysed using a Zeiss LSM 710 confocal laser scanning microscope.

Figure 6: 3T3-L1 fibroblast cells were incubated at zero of differentiation day (D0) with or without EDP (50 $\left.\mu \mathrm{g} . \mathrm{mL}^{-1}\right)$, DANA $(400 \mu \mathrm{M})$ and $\mathrm{CS}\left(200 \mu \mathrm{g} \cdot \mathrm{mL}^{-1}\right)$ for 6,12 and 24 hours. Lactosyl-ceramide was quantified by flow cytometry using FITC-anti-CD 17 antibody (anti-lactosylceramide). Immunofluorescence-labelled cell preparations were analysed with a FACS Calibur cytometer.

Figure 7: 3T3-L1 fibroblast cells were incubated at zero of differentiation day (D0) with Lactosyl-ceramide (2 and $10 \mu \mathrm{M}$ ) for 6 and 9 days. Lipid droplet accumulation was visualized the by the oil red-O staining and assessed microscopically with inverted microscope. The expression of ACDC and PPAR $\gamma$ was analysed by Quantitative RT-PCR. Results were calculated as percent of control and represent mean \pm standard deviation (S.D.) of at least three independent experiments.

Figure 8: 3T3-L1 fibroblast cells were incubated at zero of differentiation day (D0) with or without EDP (50 $\left.\mu \mathrm{g} . \mathrm{mL}^{-1}\right)$, DANA $(400 \mu \mathrm{M})$ or Lactosyl-Ceramide $(10 \mu \mathrm{M})$ for 30, 60 and $120 \mathrm{~min}$. Detection of $\mathrm{p}$-ERK and ERK were evaluated by Western-blot.

Figure 9: 3T3-L1 fibroblast cells were incubated at zero of differentiation day (D0) with or without EDP (50 $\left.\mu \mathrm{g} . \mathrm{mL}^{-1}\right)$ or Lactosyl-Ceramide $(10 \mu \mathrm{M})$ in presence or absence of U0126 $(10 \mu \mathrm{M})$ for 6 and 9 days. Lipid droplet accumulation was visualized the by the oil red-O staining and assessed microscopically with inverted microscope. The expression of ACDC and PPAR $\gamma$ was analysed by Quantitative RT-PCR. Results were calculated as percent of control and represent mean \pm standard deviation (S.D.) of at least three independent experiments. 


\section{EDPs effect on 3T3-L1 cell differentiation and viability}

Click here to access/download;Colour Figure

A

Differentiation days
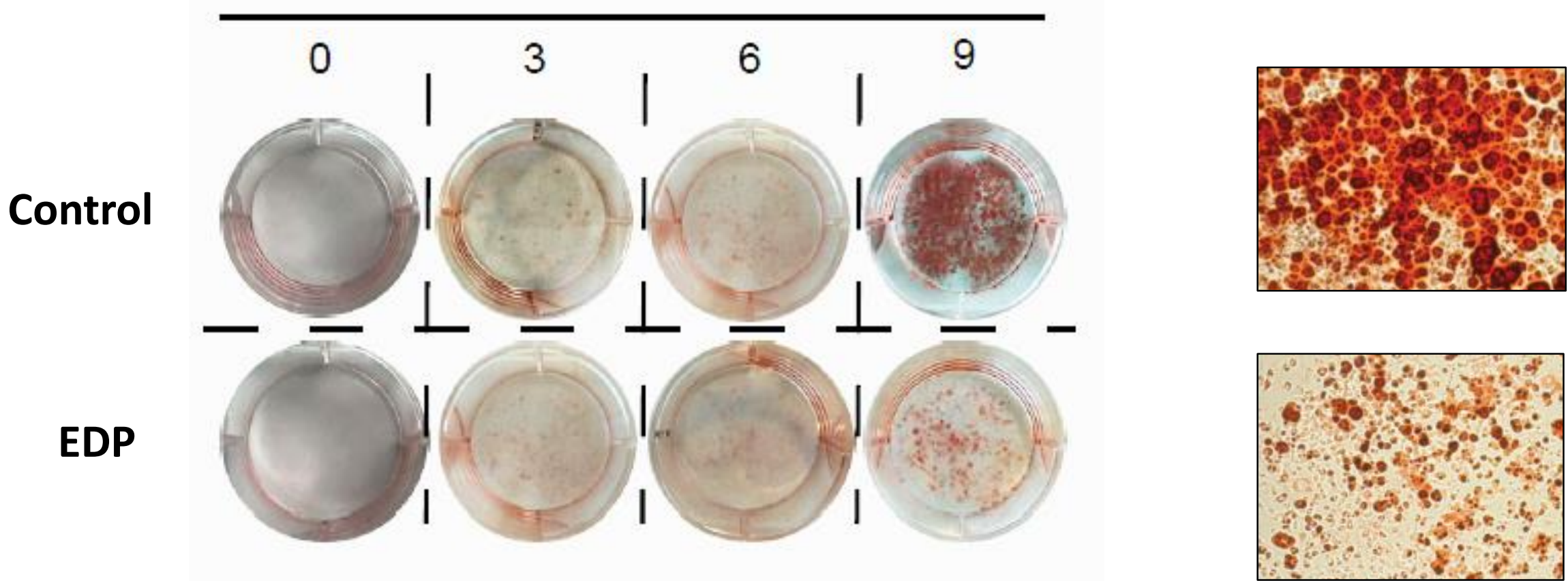

B

\begin{tabular}{|c|c|c|c|c|}
\hline Differentiation day & 0 & 3 & 6 & 9 \\
\hline $\begin{array}{c}\text { EDP-treated cells viability } \\
\% \text { versus control }\end{array}$ & $97 \pm 5.5$ & $95 \pm 6.3$ & $102 \pm 4.6$ & $94 \pm 7.1$ \\
\hline
\end{tabular}


A

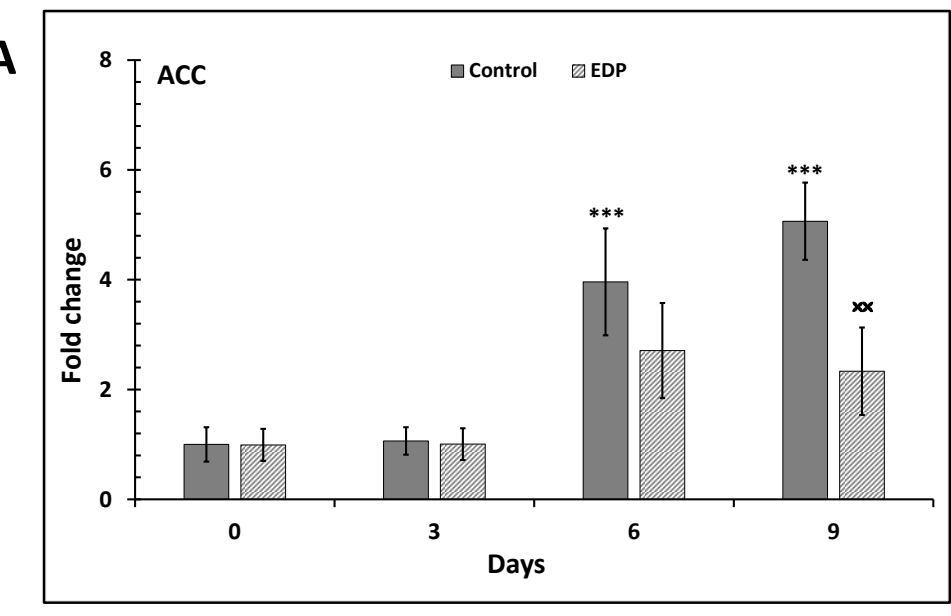

B

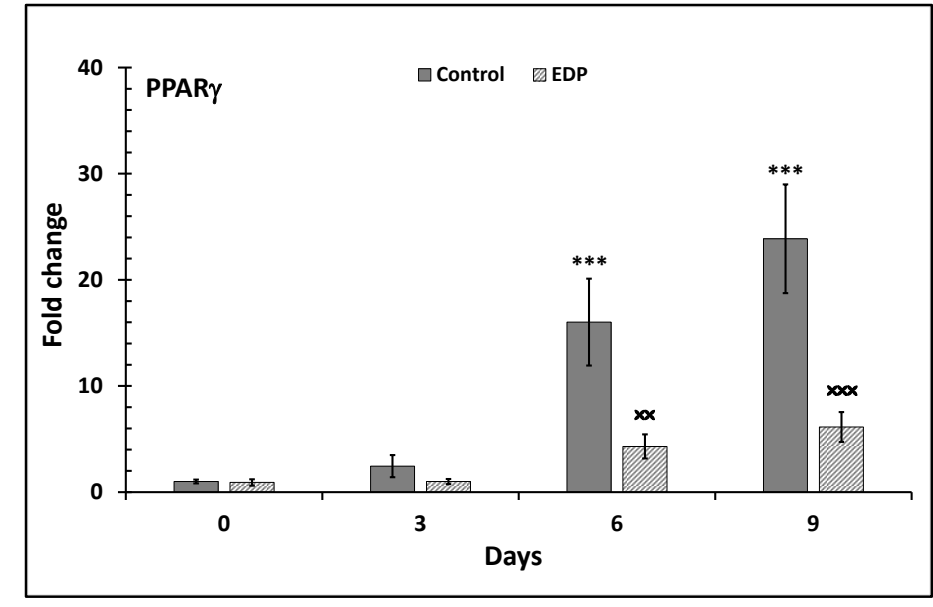

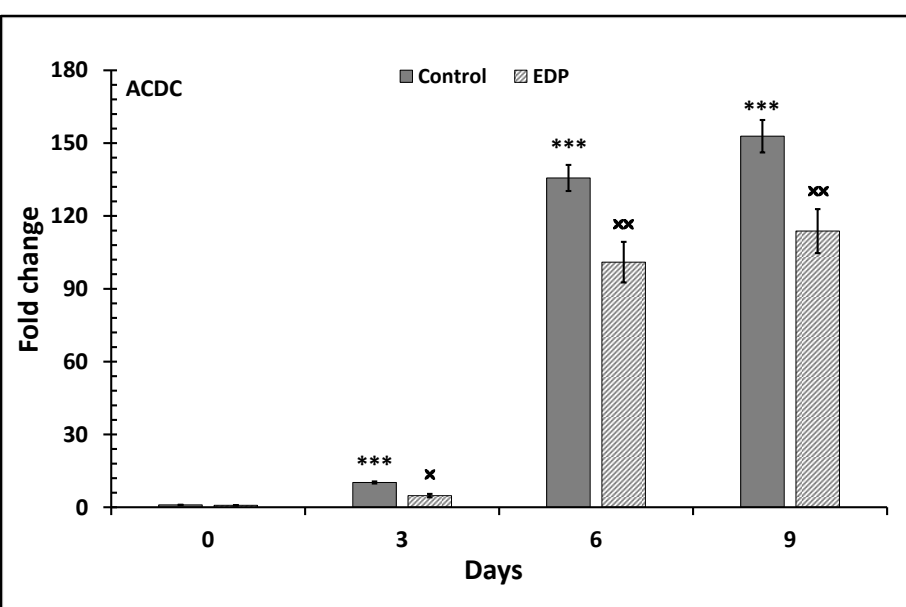
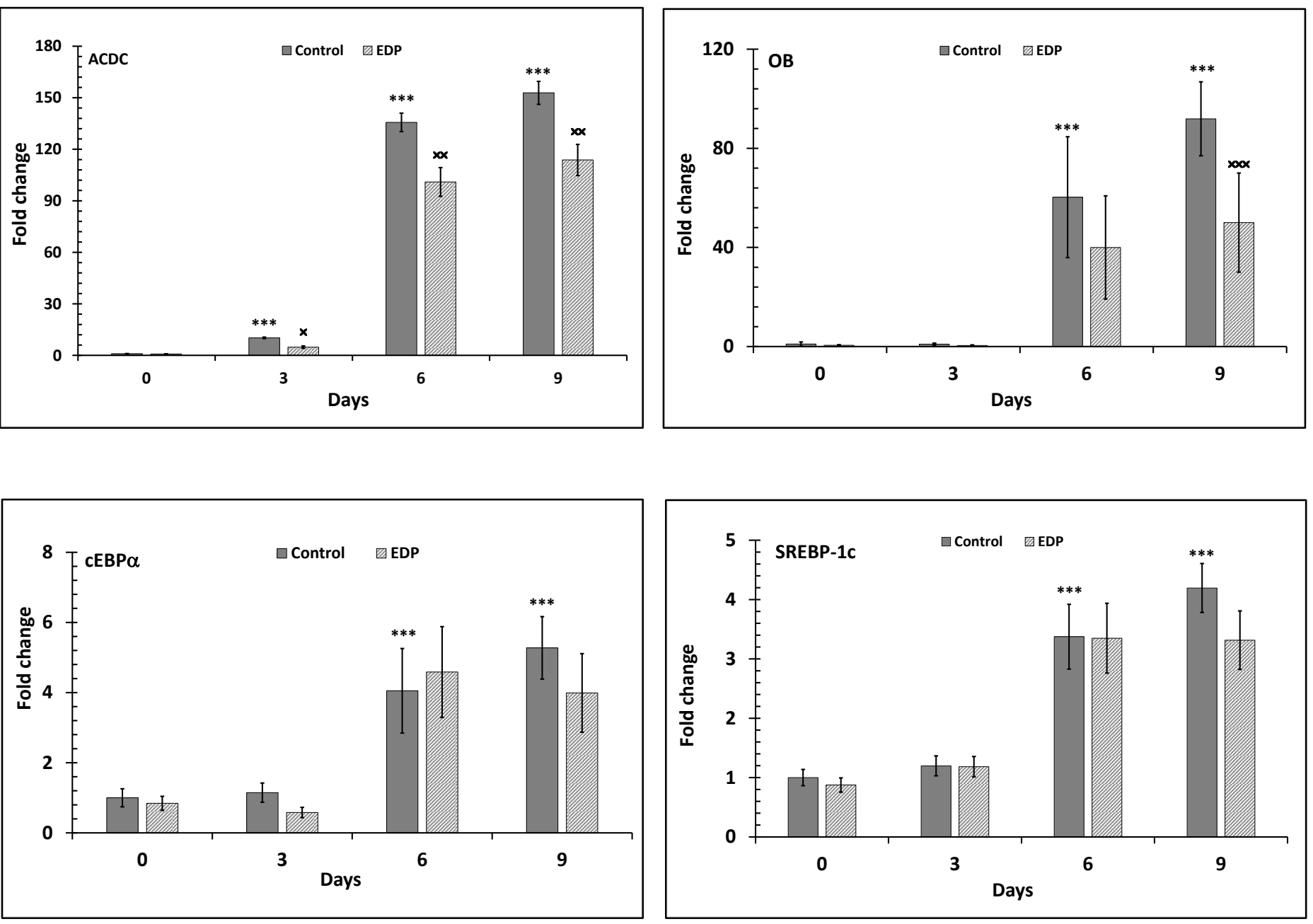

FIGURE 2 


\section{EDP \\ EDP \\ DANA \\ CS}
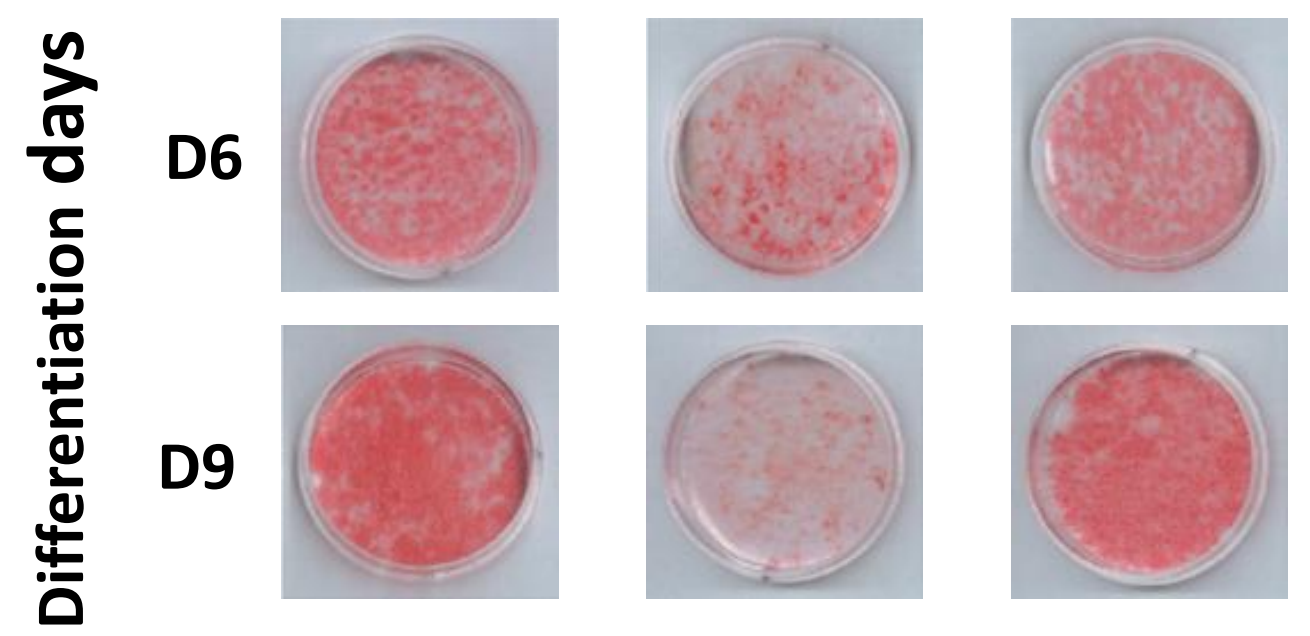

B
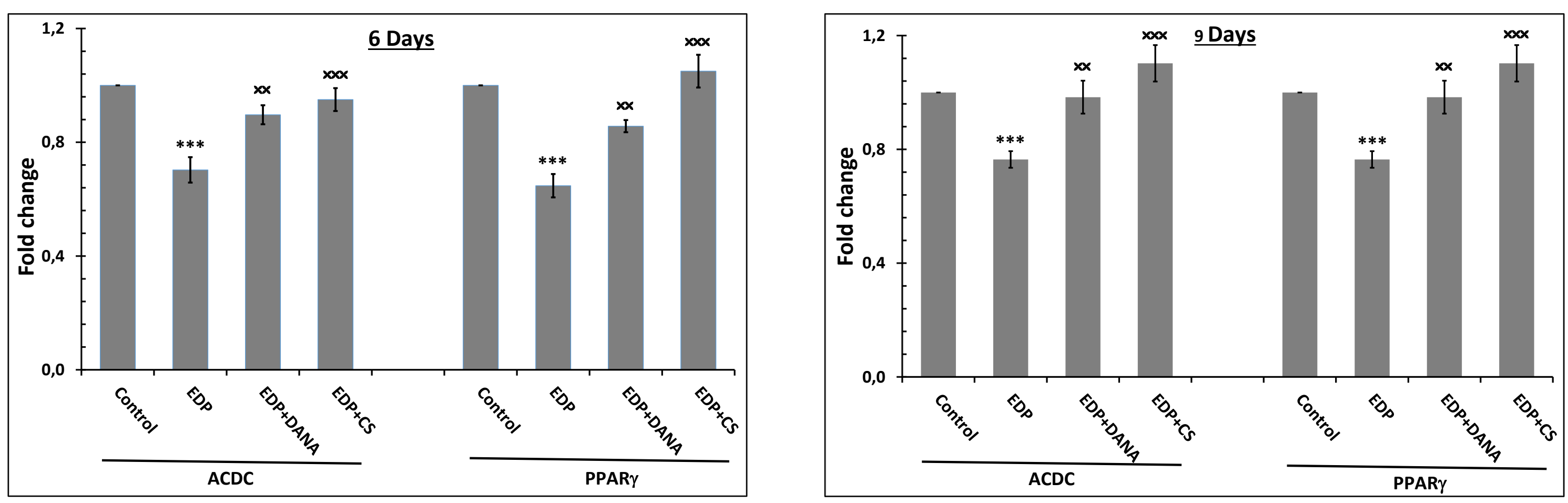

FIGURE 3 
Scramble VGVAPG

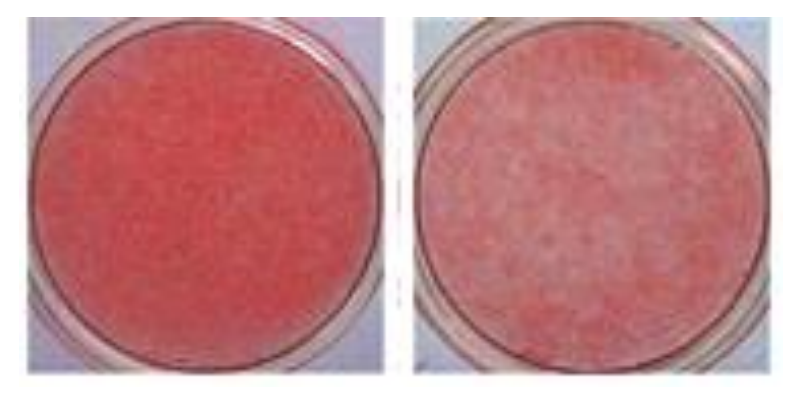

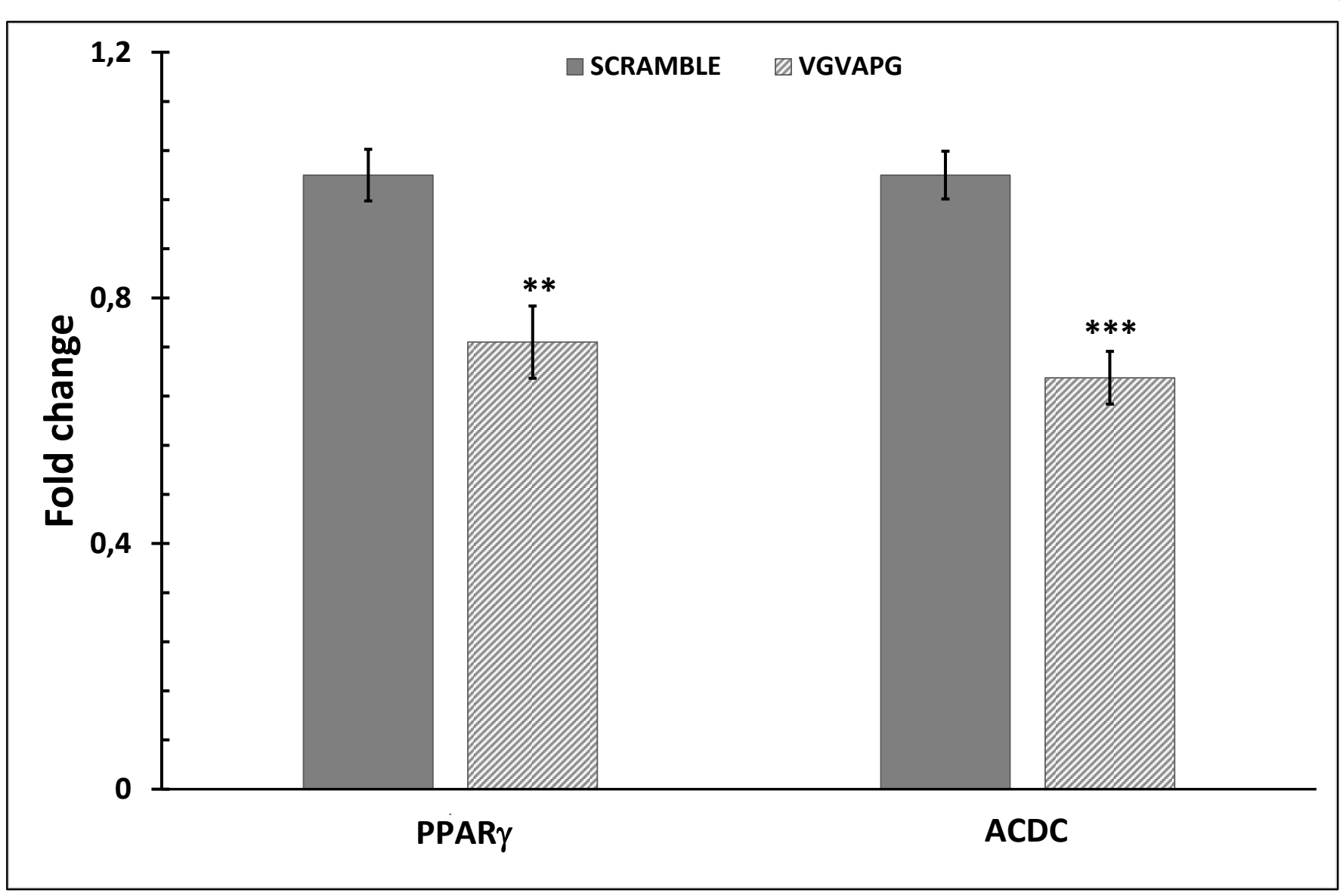

FIGURE 4 
Click here to access/download;Colour Figure

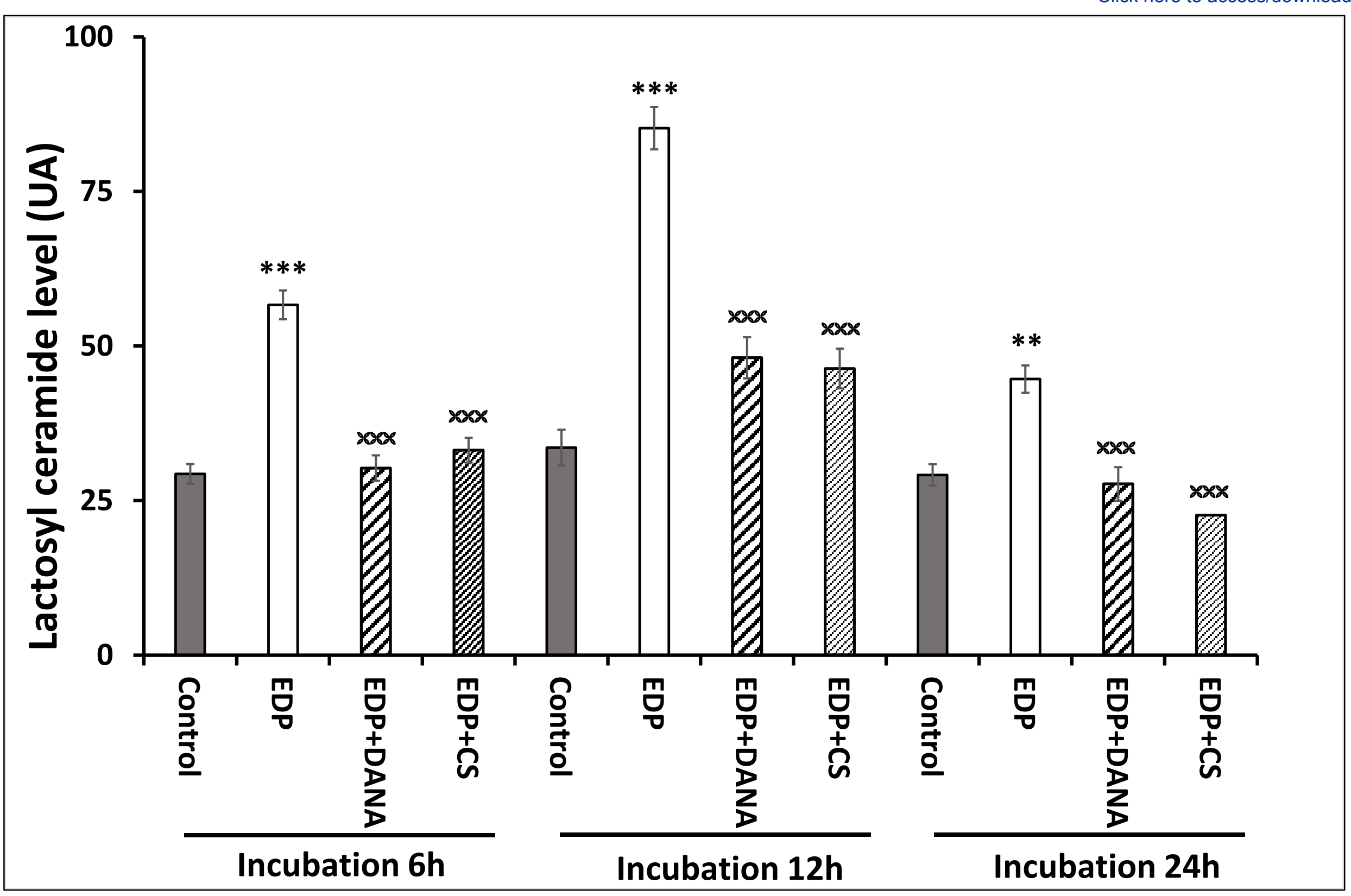

FIGURE 6 


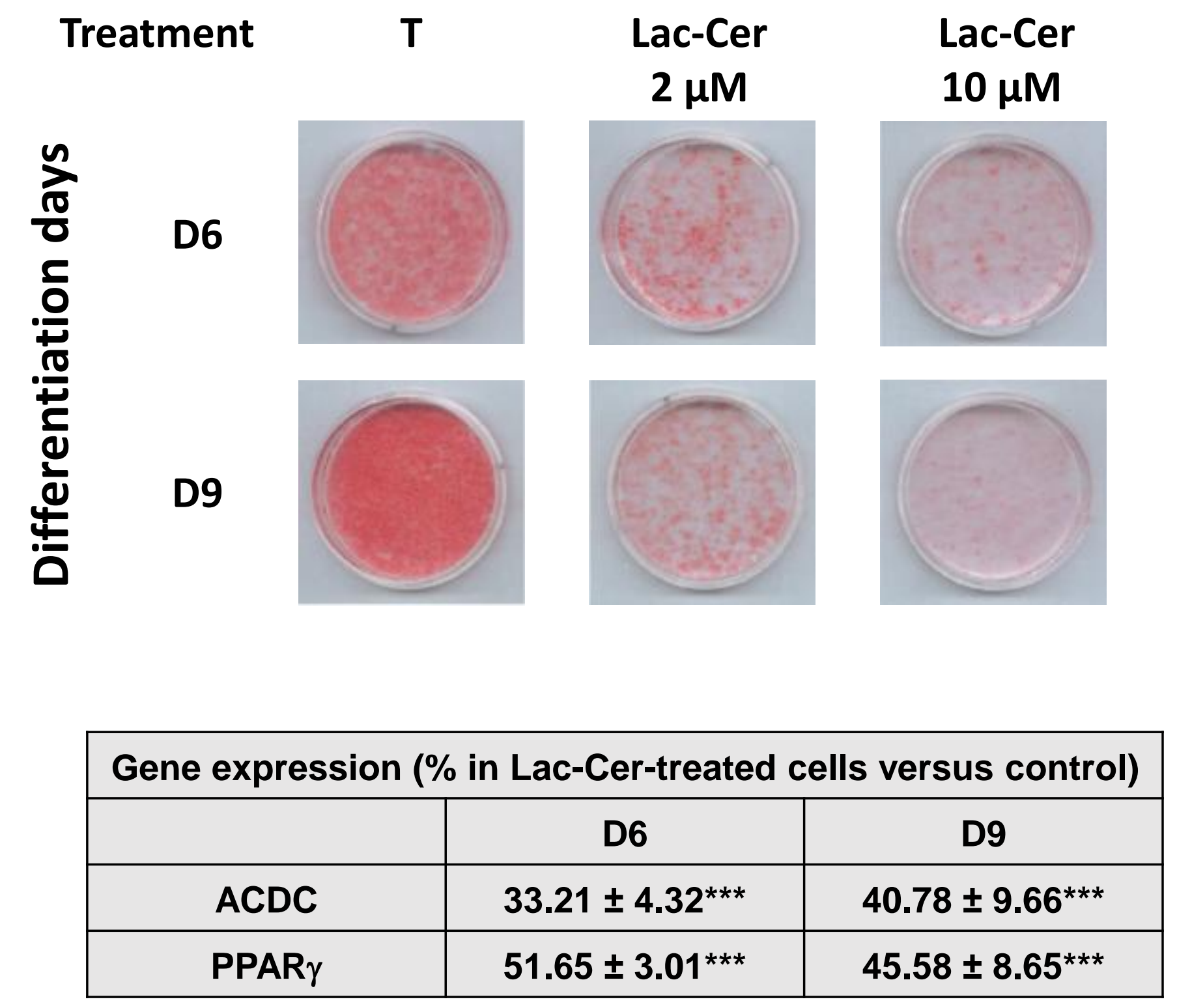

FIGURE 7 
$30 \mathrm{~min}$

EDP

DANA Lac-Cer
$60 \mathrm{~min}$

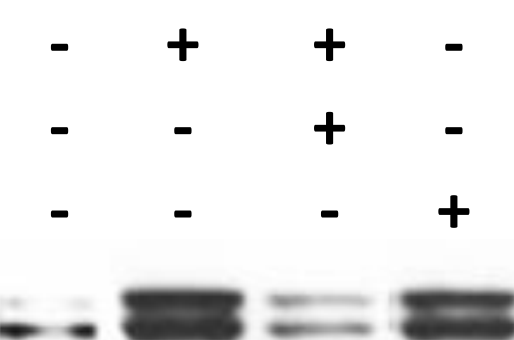

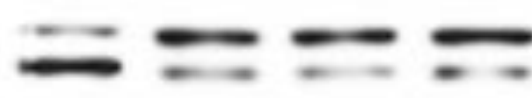

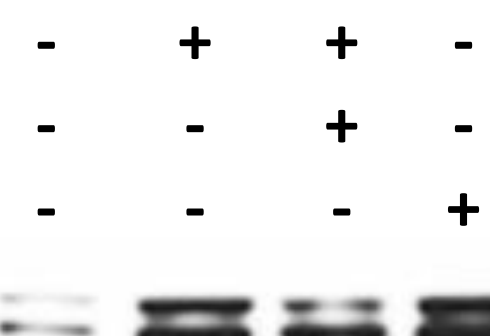

$-+$

- $\quad-\quad$ -

$\ldots=-C={ }_{\text {P.ERK }}$

ニニニニ ニニーニ

FIGURE 8 


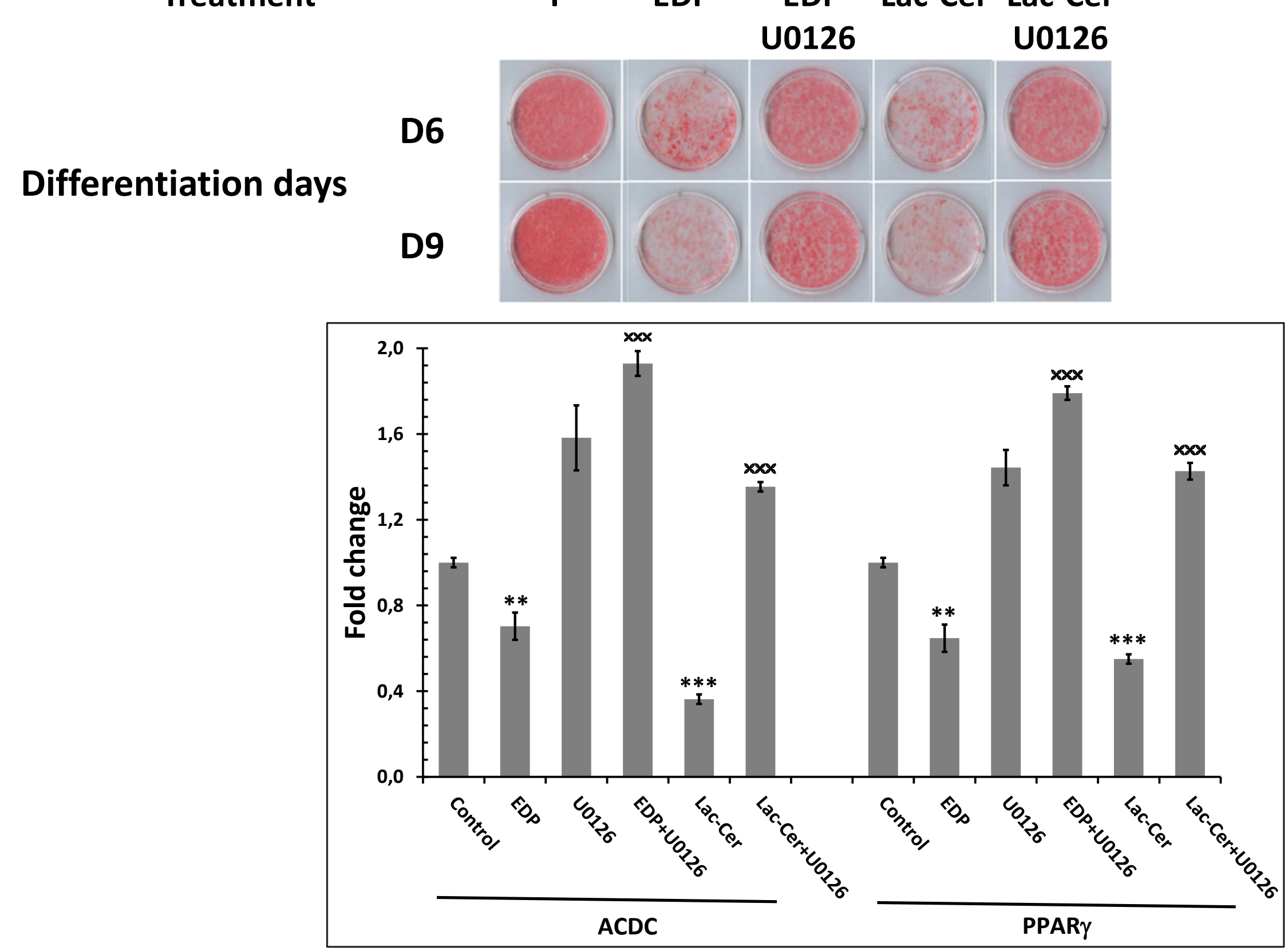

FIGURE 9 